precisely to the category of those which reverse themselves; for some are reversed and the others are on the point of being so. For the same metals, the rcversals are more or less complete according to the conditions of the experiment, and for different metals according to their chemical and physical properties.

The law of distribution of these groups presents another common character relatively to the succession of distances and intensities: the lines get nearer together towards the more refrangible end and diminish in intensity. This character is much the more striking when the number of reversed lines is considerable, because the ficld on which they appear is more uniform. It seems that with the elevation of temperature the spectrum tends towards a limit, that of a continuous brilliant background despoiled of all lines except the regular series of the self reversing ones. It is to this constitution that I wish to draw the attention of observers.

The ntrmber of metallic spectra capable of giving a regular series of spontaneously reversed lines on a continuous back. ground is considerable; but the most beautiful series that I have observed were supplied by two metals which one could scariely have anticipated, from a chemical point of view, to find side by side; these are aluminium and thallium, whose equivalents are at the extremity of the list of those of the simple bodies. The diagram gives an idea of the distribution of these reversed lines; one sees that they form in each spectrum a series of doublets fulfilling the conditions of distance and intensity given above.

I shall not stop to indicate the fruitless trials of numerical calculations that I have taken in hand in order to represent each of these series by the substitution of the series of entire numbers in a simple function; I may add that I had given up these rescarches until the discovery. of Dr. Huggins on the spectra of white stars brought back my attention to this subject.

These spectra present, in fact, a common series of dark lines, that is to say, reversed, fulfilling precisely the conclitions of distance and intensity which characterise in metallic spectra the spontaneously reversed lines: they prolong the series of well-known lines of the spectrum of hydrogen, $C, F, G, h$. One could then foresee that the whole series belonged to them; that is what has since been confirmed by Vogel, though this result is still not quite certain. The interest of this identification was such that I sought to prove it myself, which I could not realise till lately. The experiment is not without difficulty ; but in taking more minute precautions to get rid of all impurity in the hydrogen, I have seen the impurity lines obliterated, and finally I succeeded in obtaining photographs showing the series of star-lines in all their purity.

The spectrum of hydrogen is placed on the first line in the above diagram: the comparison ha; been rendered

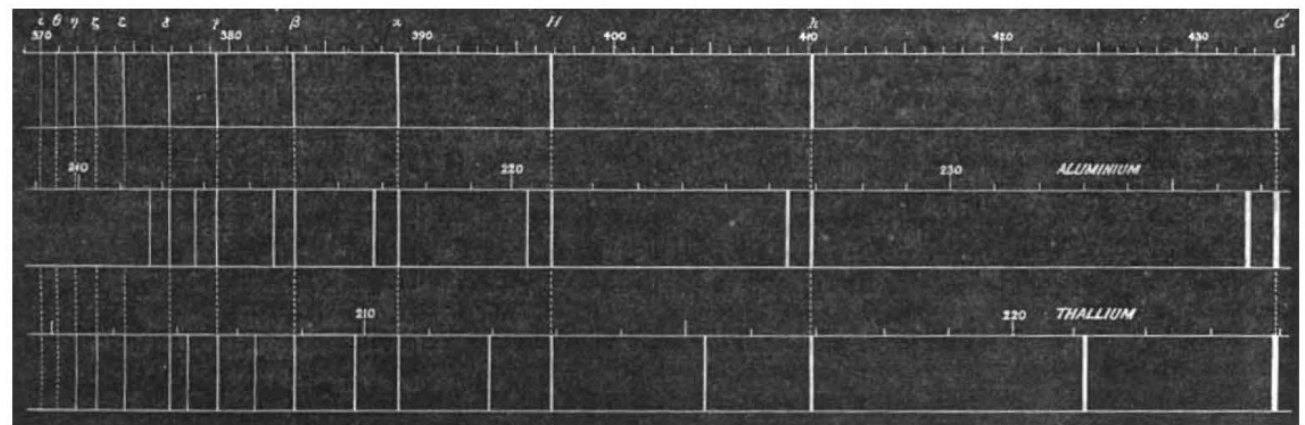

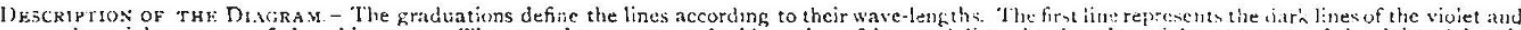
ultra-violet spectra of the white stars. The second represents a double series of inverted lines in the ultra-violet spectrum of aluminitum (electric arc). The scale of the drawing has been chosen in a manner to make (; and d coincide with the homologinus lines of the first serics (first line of each doublet). One could have operated in the same way with the second series (second lines). This mode of representation atlantageously replaces the numerical tables, showing the verification of the two empiric f.urmulas-

$$
\begin{array}{llllllll}
\text { First scries } & \ldots & \ldots & \ldots & \ldots & \ldots & \ldots & \lambda_{1}=4730+0.437^{\circ} 3 h \\
\text { Secund series } & \ldots & \ldots & \ldots & \ldots & \ldots & \ldots & \lambda_{2}=4733+0.43579 h
\end{array}
$$

which give the length of the wave of each line in function of the wave-length $h$ of the corresponding line of hydrogen; the difference between the calculation and : he ohservation is of the order of the cxperimental crrors. The third line represents a double serics of inverted lites in the utera. violet spectrum of thathism (electric arc). The scale of the drawing was chosen like the one above; the empiric formulas which represent these two series are :-

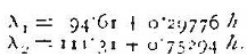

easier by the choice of scales showing intuitively the identity of the law of distribution of lines in the three spectra.

IVe might compare in the same way the more complex groups, like magncsium, zinc, sodium, Sc. ; the only diffculty is to establish the agreement of the groups; we do this immediately by a quite simple graphic construction. We arrive at the following statement, which resumes the whole of my rescarches. In the metallic spectra rertain series of lines, spontaneously reverseci, present sensibly. the same law of distribution and intensity as that of the hydrogen lines.

It is not necessary to dwell on the importance of this relation: it makes evident the existence of a law which is general relatively to the emissive powers of incandescent vapours, and, again, it shows that this law of succession of spe itral lines, common to so many series, seem: to be expressed by the help of the same function, which one might call the hydrogenic function, which should play the principal part in these studies: the result then appears to constitute a first step towards the solution of the great problems which the spectroscope brings on for solution.

$\mathrm{R}$

\section{VEGETATION OF SOUTH GEORGIA}

N Tuesday, January 17, 1775 , Capt. Conk landed on this remote jsland, which is situatcd about roon miles cast of Cape Horn, in about $54^{\circ} \mathrm{S}$. lat. and $37^{\circ} \mathrm{WV}$. long., and took possession of it in the name of King George the Ihird, after whom he named it. Capt. Cook landed in three different places, and the ceremony of adding the island to the British dominions, he informs us, was performed under a waving of colours and a discharge of small arms. Whether any British subject has ever set foot on it since that day I know not; but the description of the island by its famous discoverer was not likely to tempt any one to go out of his way with that object in vicw. Although 
lying only as far south of the equator as York is north of it, South Georgia is covered, in the higher parts at least, with permanent snows and glaciers, and is altogether of a most wild and desolate aspect. Large masses of ice were continually breaking off from the perpendicular cliffs and falling into the sea with a noise like cannon. "The inner parts of the country," says Cook, "were not less savage and horrible. The wild rocks raised their lofty summits till they were lost in the clouds, and the valleys lay covered with everlasting snow. Not a tree was to be seen, nor a shrub even big enough to make a toothpick. The only vegetation we met with was a coarse strongbladed grass growing in tufts, wild burnet, and a plant like moss, which sprung from the rocks."

Animal life, however, was more abundant. Seals were plentiful, and the penguins the largest ever seen by Cook; some which were taken on board weighed from twentynine to thirty-eight pounds. Eight kinds of "oceanic birds" are enumerated, and one, a yellow bird, was found to be delicious food. All the land birds observed were "a few small larks." From Cook's narrative it appears that Forster, the botanist, was one of the landing party, hence it might have been expected that few flowering plants would have escaped observation, especially as the visit was made in January, the midsummer of the southern hemisphere. Forster himself states ("Observations made during a Voyage round the World," p. I6) that South Georgia is an isle of about eighty leagues in extent, consisting of high hills, none of which were free from snow in the middle of January, except a few rocks near the sea. And he adds that there was no soil except in a few crevices of the rocks.

No further information respecting this island has been published, so far as I am aware, until since the return of a recent German Expedition, which made the island one of its stations for meteorological and other observations. When collecting the materials to illustrate the flora of the very much broken coldest southern zone of vegetation for the "Botany of the Challenger Expedition," I had to be content with Cook and Forster's very meagre accounts of South Georgia; but from the published northern limits of drift ice in different longitudes in the southern hemisphere, it was not expected that South Georgia possessed much more than the scanty flora they attributed to it, though Macquarie Island, in the same latitude, and nearly in the longitude of New Zealand, was known to support a comparatively luxuriant vegetation. Dreary and barren as it is, however, South Georgia is not so bad as it has been painted. The officers of the German Expedition spent nearly a year on the island, and appear to have explored it thoroughly, botanically and otherwise. During this period the atmospheric pressure was subject to extraordinary fluctuations, the extremes exhibiting a difference of 64 millimetres, or a fraction over $2 \frac{1}{2}$ inches, while the range of temperature during the same period was only $48^{\circ} \cdot 6 \mathrm{Fahr}$., or in round numbers, from $8^{\circ}$ to $57^{\circ}$ Fahr. ; thus showing the freezing-point to be nearly midway in the range. The actual mean temperature of the year was $35^{\circ} .06$ Fahr. ; of June, the coldest month, $25^{\circ} \cdot 6 \mathrm{Fahr}$; and of February, the warmest month, $4 \mathrm{I}^{\circ} \cdot 6 \mathrm{Fahr}$.

With regard to the flowering plants collected in the island by Dr. Will, one of the officers of the Expedition, we are indebted to Dr. Engler for an enumeration of them in his fahrbiücher, vol. vii. p. 281. They are thirteen in number, and their general distribution is so extremely interesting that I may be pardoned for giving it in detail :-

(I) Ranunculus biternatus, Sm. (Ranunculaceæ).Fuegia, Falklands, Tristan d'Acunha (?) Marion, and Kerguelen Islands.

(2) Colobanthus subulatus, d'Urville (Caryophyllaceæ). -Fuegia, Campbell's Island, New Zealand, and Alps of Victoria, Australia.
(3) Colobanthus crassifolius, d'Urville (Caryophyllaceæ). -Fuegia and Falklands.

(4) Montia fontana, L. (Portulaceæ).-Fuegia, Marion, Kerguelen, Campbell's Island, and widely diffused.

(5) Acona adscendens, Vahl. (Rosaceæ). - Fuegia, Marion, Crozets, Kerguelen, Macquarie Islands, and New Zealand.

(6) Acana lavigata, Ait. (Rosaceæ).-Fuegia.

(7) Callitriche verna, L. var. (Halorageæ).-Fuegia, Marion, Kerguelen, Heard Islands, New Zealand, and widely diffused.

(8) Funcus nover-zealandice, Hook. f. (Juncaceæ).--New Zealand.

(9) Rostkovia magellanica, Hook. f. (Juncaceæ).-Andes, Fuegia, Falklands, and Campbell's Islands.

(Io) Aira antarctica, Hook. f. (Gramineæ).--Fuegia, Falklands, South Shetlands, and Kerguelen Island.

(I I) Phleum alpinum, L. (Gramineæ).-Magellan's Straits, and widely dispersed in the cold regions of the northern hemisphere.

(12) Festuca erecta, D'Urville (Gramineæ).-Fuegia, Falklands, and Kerguelen.

(I3) Poa flabellata, Hook. f., syn. Dactylis cespitosa, Forst. (Gramineæ).-Fuegia and Falklands.

From the collector's remarks, appended by Engler to each species, it appears that some of the foregoing plants flourish Iuxuriantly in South Georgia, especially the species of Acana (the burnet of Cook's narrative), and Aira antarctica and Poa flabellata. The Ranunculus was abundant by the side of a stream and elsewhere, and Colobanthus subulatus (doubtless the moss-like plant mentioned by Cook) formed large tufts on the south side of the hills. Nine out of the thirteen plants in South Georgia are also found in the eastern part of this southernmost zone of vegetation from Kerguelen to New Zealand, taking these islands together. One, funcus nova-zealandia, had not previously been found in what may be termed the American part of the zone; but, as Prof. Buchanan, to whom Dr. Engler submitted the South Georgian specimens, remarks, this is so nearly allied to the South American Funcus stipulatus that it may be cited as another instance of representative and closely-allied species in the American and Australian regions.

Thus are we gradually obtaining a knowledge of the vegetation of the detached fragments of the Antarctic flora; yet several islands are still quite unknown botanically or only very imperfectly. Concerning Diego Alvarez, or Gough Island, situated about $4^{\circ}$ south of the Tristan d'Acunha group, we know nothing except that the vegetation is said to be similar to that of Tristan d'Acunha, and to include Phylica nitida, the only arbor eous member of the latter flora. Then there is a group of islands, including Lindsay, Bouvet, and Thomson, in about the same latitude as South Georgia, but $35^{\circ}$ eastward, of which nothing is known botanically.

W. Botting Hemsley

\section{NOTES}

THE Visitation of Greenwich Observatory takes place on Saturday next.

The Ladies' Soirée at the Royal Society takes place on the evening of Wednesday, the 9 th inst.

THE honour of C.M.G. has been conferred on Mr. Charles Meldrum, Director of the Royal Alfred Observatory, Mauritius.

THE explosion of the 43 -ton gun has led to the appointment of a Committee of Inquiry, in which the name of Mr. Anderson is conspicuous by its absence, although surely no greater authority on the points at issue exists. A year ago, in his important lectures at the Society of Arts, he drew attention to the want of relation between the sections and pressures, and predicted disasters. 